\title{
Bionomic Survey of Anopheles Mosquitoes in Alusi Kelaan and Waturu on 2016
}

\author{
Ivon Ayomi $^{1 *}$, Melda Suebu ${ }^{1}$, Mardi Rahardjo ${ }^{1}$ \\ ${ }^{1}$ Centre for Papua Health Research and Development Papua, Indonesia \\ *Corresponding author. Email: ivon.ayomi121@gmail.com
}

\begin{abstract}
Indonesia is one country that is still at risk of malaria. The high intensity distribution of malaria in Indonesia is found in forested areas, especially in Eastern Indonesia. Malaria cases are mainly reported from outside Java, namely in Papua, Maluku, Nusa Tenggara, Kalimantan and Sumatra. This study was conducted to obtain and survey bionomic Anopheles sp in Saumlaki, West Southeast Maluku Regency (MTB). The crosssectional study was conducted at the Aulusi Kelaan Health Center, Komormolin District and Waturu Health Center, Nirumas Sub-District, West Southeast Maluku Regency. The entomological survey in the form of larvae density survey was carried out in Aulusi and Waturu. Collection of Anopheles $s p$ adult mosquitoes by using landing man from 18.00-06.00 and Anopheles habitat survey. Anopheles sp habitat was found in water reservoirs from car tires, drums, ponds, used boats and semi-permanent ponds. The results were obtained by several types of Anopheles $s p$ including Anopheles flavirostris (91\%), Anopheles barbirostris group (8.2\%), Anopheles farauti (0.9\%) and Anopheles koliensis (0.04\%). Anopheles flavirostris and Anopheles barbirostris group have quite high species density. The activity bites Anopheles sp on average from 22.00-23.00 and is more commonly found outside the home. Anopheles $s p$ mosquito found in West Southeast Maluku Regency is An. flavirostris, An. barbirostris group (An. barbirostris and An. campestris), An. farauti and An. Koliensis and the average biting activity at $22.00-23.00$. Based on the results, it is adviable to reduce activities outside the house at night. If you have to do activities at night, it is recommended to use repellent or long-sleeved clothes to prevent anopheles mosquito bites.
\end{abstract}

Keywords: bionomic, Anopheles

\section{INTRODUCTION}

The World Malaria Report in 2011 stated that malaria occurred in 106 countries and even 3.3 billion of the world's population lived in areas at risk of contracting malaria. The number of malaria cases in the world is 216 million, of which 28 million occur in ASEAN. Each year 660,000 people die from malaria, especially children under five $(86 \%), 320,000$ of whom are in Southeast Asia including Indonesia [1]. Malaria is a health problem in the community that can cause death especially in high-risk groups, such as infants, toddlers, and pregnant women. In addition, malaria directly causes anemia and can reduce work productivity [2].

Malaria is still found in all provinces in Indonesia. Based on annual parasite incidence (API), stratification is carried out in areas where Eastern Indonesia is included in the stratification of high malaria, moderate stratification is in some areas in Kalimantan, Sulawesi and Sumatra, while in Java-Bali it is included in low stratification, although there are still villages / focus of high malaria [3]. Indonesia is one country that is still at risk of malaria, especially eastern Indonesia, $80 \%$ of districts / cities are still included in the malaria endemic category and $45 \%$ of the population live in areas at risk of contracting malaria. especially outside Java, namely: Papua, Maluku, Nusa Tenggara, Kalimantan and Sumatra [4].

Maluku Province is one of the malaria endemic areas with a morbidity rate of Annual Parasite Incidence (API) in 2008 of $12.30 / 1000$ in 2009 population of $7.00 / 1000$ population, in 2010 of $10.40 / 1000$ population and in 2011 of 11.40 / 1000 population [2]. Central Maluku Province, East Seram is a high malaria endemic area (API.10 / 00). While the regions of Buru Island, Central Maluku, Ambon and Tual are moderate endemic (API 1-10 0/00) [4].

Clinical malaria rates in 2005 were $7.50 / 00$ in the Saumlaki Health Center (Tanimbar Island), 130.40 / 00 in the Ilwaki Health Center (Wetar Island). The clinical malaria rate in 2010 was 509 cases, in 2011 there were 846 cases and in 2012 there were 266 cases (Kab.Maluku Tenggara Barat), 2013 with API (53.5) and 2014 with API (29.99) [4].

One method in controlling malaria vectors that is still carried out today is by chemical means using insecticides through the use of insecticide-treated mosquito nets. Insecticides are chemicals and non-chemicals used to 
control insects. thus suppressing malaria cases. several methods include applying the IRS and ITNs. including LLINs and administration of anti-Malaria drugs [5].

The spread of mosquitoes is largely determined by environmental factors that make up an ecosystem. In an ecosystem, of course, strongly influenced by abiotic, biotic and chemical factors. Abiotic environment includes temperature, humidity, intensity of solar radiation, climate, rainfall.

While biotic factors include terrestrial vegetation, pond aquatic vegetation, rivers, swamps, the presence of predators [6]. The high prevalence of malaria in West Southeast Maluku is due to inadequate malaria vector bionomic data so that eradication of malaria vectors still faces obstacles. The vector species in each region will be bionomically different so that the species and the bionom vector will be understood so that the elimination strategy can be done effectively and efficiently according to local conditions. This research will be conducted with the aim of conducting a mosquito bionomic survey, Identiflying the habitat and breeding grounds of Anopheles mosquito larvae and measuring the level of mosquito density in West Southeast Maluku Regency precisely in Alusi and Waturu villages where both villages are villages with high malaria cases.

\section{METHOD}

This research sites in 2 locations namely in Alusi Kelaan village and Waturu village in West Southeast Maluku Regency in March- April and Mei - October 2016. The survey was carried out in a cross sectional descriptive manner. The population of this study were all Anopheles mosquitoes in Alusi village and Waturu villages, while the sample is the number of mosquitoes caught Catching mosquitoes carried out at 18:00 to $06: 00$ by 6 people. Anopheles mosquito larvae habitat survey and environmental survey of physical conditions were conducted in the morning from 7 to $10 \mathrm{am}$.

\section{RESULTS AND DISCUSSION}

\section{Results}

Table 1. Types of larvae found in several habitats in Alusi Kelaan Village and Waturu Village, West Southeast Maluku Regency

\begin{tabular}{|c|c|c|c|}
\hline \multirow{2}{*}{ Habitat Type } & \multicolumn{3}{|c|}{$\begin{array}{c}\text { The larvae of Anopheles sp were } \\
\text { found/ larva }\end{array}$} \\
\hline & $\begin{array}{c}\text { An. } \\
\text { farauti }\end{array}$ & $\begin{array}{c}\text { An. } \\
\text { flavirostris }\end{array}$ & $\begin{array}{c}\text { An. } \\
\text { barbirotri } \\
\text { s group }\end{array}$ \\
\hline Conduit & 0 & 3 & 2 \\
\hline Puddle pool & 5 & 9 & 6 \\
\hline $\begin{array}{l}\text { Puddle on the } \\
\text { boat }\end{array}$ & 5 & 0 & 0 \\
\hline Total & 10 & 12 & 8 \\
\hline
\end{tabular}

The table above shows the habitat type of larva Anopheles found in Kelaan Village and Waturu Village where the puddle of water on the boat sampan was most found An.farauti, on puddle pool was found An.farauti, An flavirostris and An.barbirostris group and on conduit was most found An.flavirostrisand An.barbirostris group

Table 2. Physical and environmental conditions of several Anopheles spp larvae habitats in Alusi Kelaan and Waturu villages, West Maluku Regency.
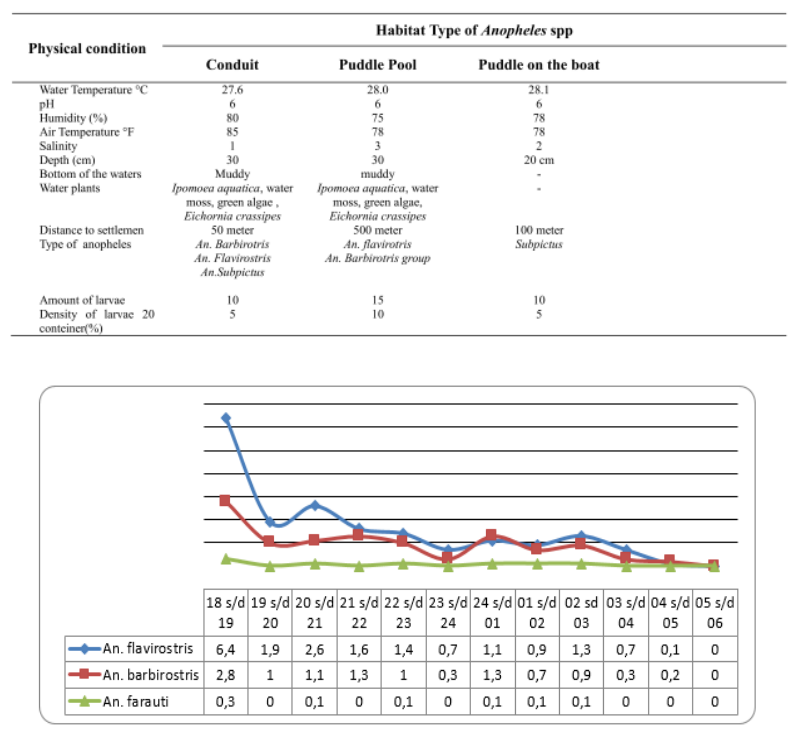

Figure 1. shows the level of density An. flavirostris, An.Barbirostris in Alusi village based on arrest hours in May-June 2016 


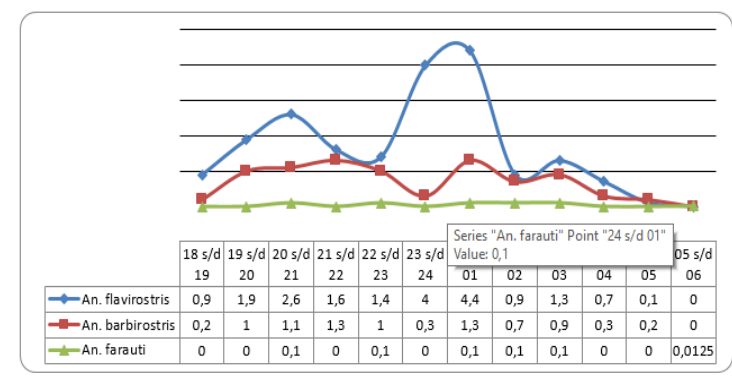

Figure 2. shows the level of density An. flavirostris, An.Barbirostris in Alusi village based on arrest hours in September - October 2016

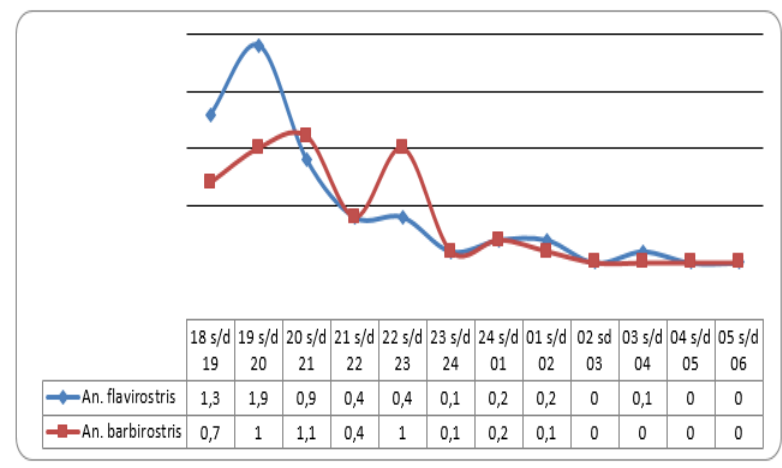

\section{Discussion}

The results of habitat surveys in the Alusi Kelaan Puskesmas and Waturu Puskesmas areas showed that Anopheles $s p$ was mostly found in waterways, ponds, ripples, puddles on boats / canoes. Anopheles sp species found in these habitats are: An. farauti, An. flavirostris, and An. barbirostris group. Anopheles spp larvae were found in residential areas and coconut plantations. Based on interviews with the local health officials, Anopheles spp habitat was formed due to human activities such as the construction of bridges and road widening that eventually formed puddles in the rainy season. Semi-permanent ponds and irrigation channels, blocked by wood and leaves waste also have the potential to become Anopheles sp.

The result of catching mosquitoes in Alusi kelaan village was that no adult mosquitoes were found in the village but they were found in garden houses in the Weloka Area where the distance between the Alusi village and the garden houses in Weloka is $\pm 1 \mathrm{~km}$, which is very potential for the malaria transmission. Malaria transmission is very potential because, based on the results of interviews with the community, they are more active in the garden Monday - Saturday

Catching mosquitoes in the village of Waturu, anopheles mosquitoes were not found in the village but were found at the location of the house near the garden and the distance between the garden house and the settlement $\pm 500 \mathrm{~m}$ so that it has the potential for malaria transmission, where the community works daily in the garden.

Catching mosquitoes in the districts of MTB was carried out in two different seasons in May - June, still catching
Figure 3. shows the density level of An. flavirostris, An.Barbirostris in waturu village based on the hours of arrest in May-June 2016

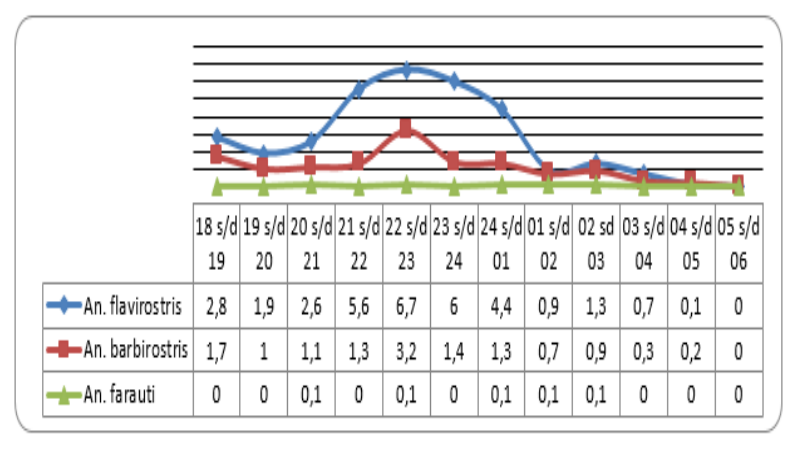

Figure 4. shows the density level of An. flavirostris, An.Barbirostris in Waturu village based on the hours of arrest in September - October 2016

the east wind (after the rainy season) so that the number of mosquitoes that were caught> 300 animals / night. 19.00 and decreased at $05.00-06.00$, while for the Waturu Health Center area there was a mosquito density at 18.00 19.00 and a decline at 02.00 - 06.00. This can be connected with data from BMKG, West Southeast Maluku Regency, where in May - June the weather, temperature, humidity are very suitable for mosquito development.

In the months of September - October, the West wind season has begun, when there is a change in the time of density of mosquitoes at the fishing location. For Alusi Puskesamas, the density occurs at $20.00-21.00$ then at 22.00 decreases and at $23.00-24.00$ increases again and decreases at $05.00-06.00$, for Puskesmas Waturu there is an increase at $22.00-23.00$ and decreases at $05.00-06.00$, and for Puskesmas Ilwaki occurs at 23:00 - 24.00 and decreases at $05.00-06.00$. this can be connected with data from BMKG, West Southeast Maluku Regency, where in September - October, the weather, temperature, humidity are very suitable for mosquito growth.

\section{CONCLUSION}

Anopheles mosquitoes found in West Southeast Maluku Regency were An.flavirostris, An barbirostris group (An barbirostris and An.campestris) An.farauti and An.subpictus. Habitat of larva breeding in Alusi kelaan village and Waturu village were An.farauti and An.subpictus, Habitat where larva breeding occurs in Alusi kelaan village and Waturu village were conduit, puddles 
[3] Kementerian kesehtan RI,Jendela Data dan Info Kesehatan Epidemiologi Malaria di Indonesia, Buletin malaria,Triwulan I, 2011

and boat, larvae found An.farauti and An.subpictus, in one year affect the density of captured mosquitoes. In the east wind season (after the rainy season) between June and June the number of mosquitoes caught is greater than in the west wind season between September - October.

\section{ACKNOWLEDGMENT}

Thank you to the head of the South West Southeast Maluku Department of Health Dr. Juliana Ratuanak, Head of P2M Health Office of MTB Ibu KA Candra Utakaman, head of puskesmas Alusi kelaan Mr. Thomas Lakafin head of puskesmas waturu Mr. C.J.Batilmurik and all until the completion of this research.

\section{REFERENCES}

[1] WHO Guidelines for testing mosquito adulticides for indoor residual spraying and treatment of mosquito nets ,2011

[2] Kementerian Kesehatan RI, Pedoman Penatalaksanaan kasus malaria di Indonesia, Direktorat Jenderal pengendalian penyakit dan penyehatan lingkungan 2012
[4] Provinsi Maluku.profil dinas kesehatan maluku

2013.http://www.depkes.go.id/download/PRO FIL_KESPROVINSI_2013/30_Profil_Kes.pro v.Maluku.2013.pdf

[5] Provinsi Maluku.profil dinas kesehatan maluku

2012.http://www.depkes.go.id/download/PRO FIL_KESPROVINSI_2012/30_Profil_Kes.pro v.Maluku.2012.pdf

[6] Insecticide-Treated Nets - National Geographic

Education.http://www.cdc.gov/malaria_world wide/reduction/itn.html

[7] Munif, A. Panduan Pengamatan Nyamuk Vektor Malaria. Penerbit Sagung Seto Surabaya. 